\title{
Influence of varying estrogen levels on trigeminal CGRP release in healthy women
}

\author{
K Ibrahimi ${ }^{*}$, AHJ Danser ${ }^{1}$, CM Villalón ${ }^{2}$, AH van den Meiracker ${ }^{1}$, A MaassenVanDenBrink $^{1}$ \\ From The European Headache and Migraine Trust International Congress \\ London, UK. 20-23 September 2012
}

Migraine is 2-3 times more prevalent in women than in men, with frequent perimenstrual attacks. TRPV1 receptors on sensory nerve endings of the trigeminal track are important in mediating migraine attacks by releasing the vasodilator calcitonin gene-related peptide (CGRP). Variation in estrogen levels during the menstrual cycle may have an influence on the sensitivity of the TRPV1 receptor or on the amount of CGRP in perivascular nerve terminals and hence on CGRP release. Capsaicin, the active ingredient of hot chili peppers, stimulates the TRPV1 receptor and causes CGRP-dependent vasodilatation [1]. We set up a model to study trigeminal CGRP release in humans. We compared the vasodilator effects of capsaicin application and electrical stimulation on the forehead skin. Healthy women, not using hormonal contraceptives (age: 18-45, $\mathrm{n}=14$ ), were studied with a Laser Doppler Imager on day 19-21 of their menstrual cycle and on day 1-2 of their menstruation. A $0.2 \mathrm{mM}$ and a $20 \mathrm{mM}$ capsaicin solution were applied to the skin. In addition, iontophoresis of saline was performed as a TRPV1-independent stimulus. Increases in dermal blood-flow (DBF) were measured. Blood samples were collected to measure estrogen levels. We measured higher DBF responses to application of $0.2 \mathrm{mM}$ capsaicin (Max:226 \pm 34 a.u.) and $20 \mathrm{mM}$ capsaicin (Max:507 \pm 39 a.u.) during day 1-2 (low estrogen levels: $15 \pm 2 \mathrm{pg} / \mathrm{ml}$ ) of the menstruation, than during day 19-21 (high estrogen levels: $67 \pm 9 \mathrm{pg} / \mathrm{ml}$ ) of the menstrual cycle (Max:176 \pm 34 a.u. and $432 \pm 33$ a.u. for $0.2 \mathrm{mM}$ and $20 \mathrm{mM}$, respectively, $\mathrm{P}<0.05)$. There was no difference in DBF responses to electrical stimulation of the forehead skin, suggesting that the observed changes are related to the sensitivity of the TRPV1 receptor. Our results indicate an influence of variation in estrogen levels on trigeminal CGRP release, with the highest reactivity observed around the menstruation when estrogen levels are low. This

${ }^{1}$ Erasmus MC, Netherlands

Full list of author information is available at the end of the article mechanism may, at least partly, explain the high incidence of migraine attacks during the perimenstrual period.

Author details
${ }^{1}$ Erasmus MC, Netherlands. ${ }^{2}$ Cinvestav Coapa, Mexico.

Published: 21 February 2013

Reference

1. Sinclair SR, Kane SA, Van der Schueren BJ, et al: Inhibition of capsaicininduced increase in dermal blood flow by the oral CGRP receptor antagonist, telcagepant (MK-0974). Br J Clin Pharmacol 2010, 69:15-22.

doi:10.1186/1129-2377-14-S1-P123

Cite this article as: Ibrahimi et al:: Influence of varying estrogen levels on trigeminal CGRP release in healthy women. The Journal of Headache and Pain 2013 14(Suppl 1):P123.

\section{SpringerOpen ${ }^{\circ}$}

( 2013 Ibrahimi et al; licensee Springer. This is an Open Access article distributed under the terms of the Creative Commons Attribution License (http://creativecommons.org/licenses/by/2.0), which permits unrestricted use, distribution, and reproduction in any medium, provided the original work is properly cited.
Submit your manuscript to a SpringerOpen ${ }^{\circ}$ journal and benefit from:

- Convenient online submission

- Rigorous peer review

- Immediate publication on acceptance

- Open access: articles freely available online

- High visibility within the field

- Retaining the copyright to your article

Submit your next manuscript at $>$ springeropen.com 